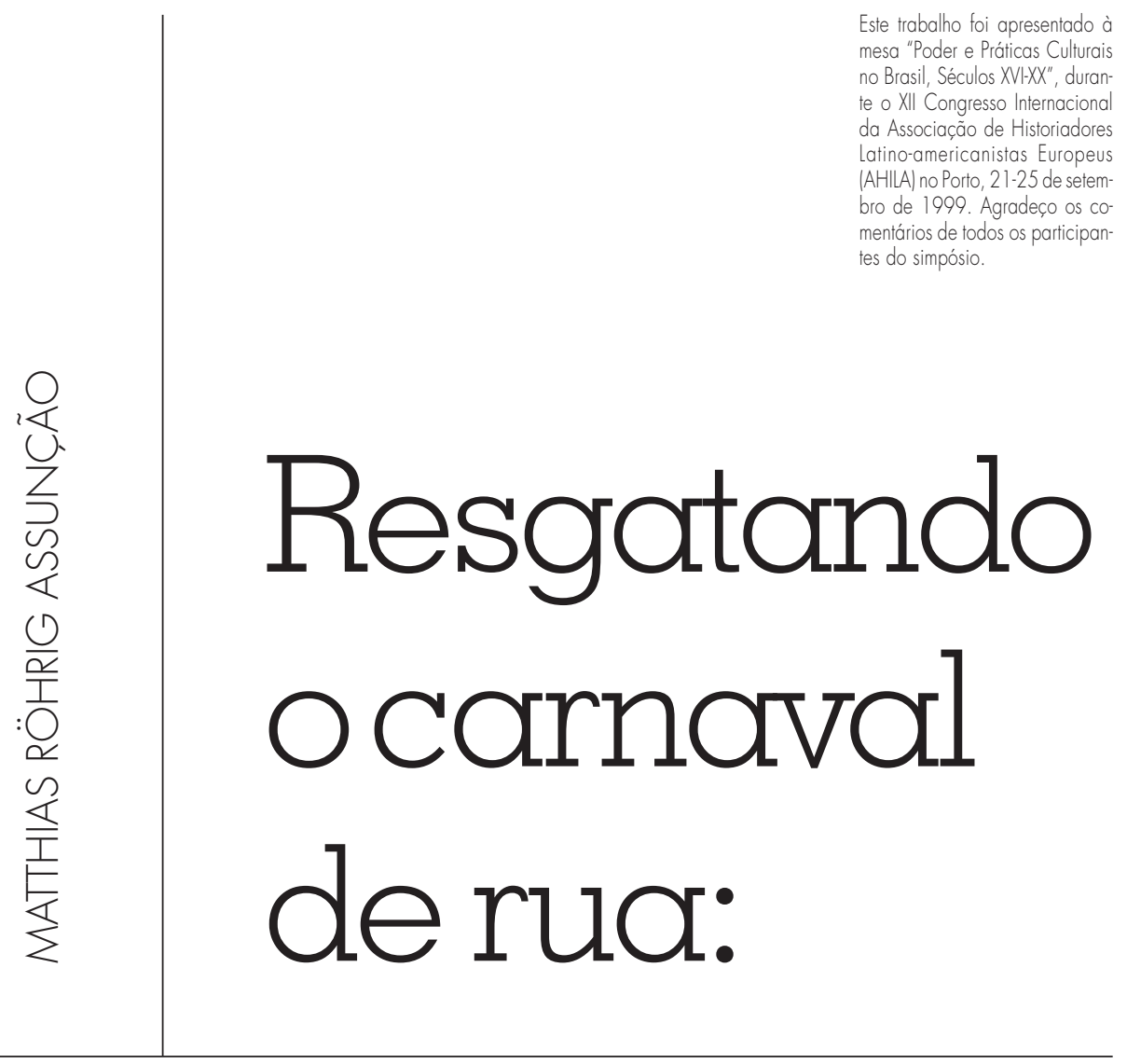

\title{
afuzarcamaranhense
}<smiles>ClO[Ga]Cl</smiles>

homogeneização

nacional-global

MATTHIAS RÖHRIG

ASSUNÇ̃̃O é professor de História da América Latina na Universidade de Essex (Inglaterra) e autor, entre outros, de A Guerra dos Bem-te-vis. A Balaiada na Memória Oral (Sioge). 
“A Madre Deus antiga

É a flor de São Luís

pela própria natureza

A sua batucada é que acaba com a tristeza"

(Caboclinho, do CD Regional 310).

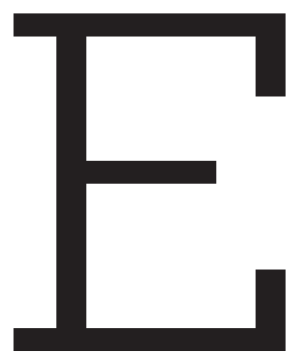

xiste uma unidade fundamental das manifestações carnavalescas nas diferentes regiões e cidades brasileiras, afirma $\mathrm{Ma}$ ria Isaura Pereira de Queirozem recente estudo (1). Estas não somente teriam as mesmas origens, mas teriam passado também pelas mesmas grandes transformações, e seguido as mesmas orientações (2). Dada esta homogeneidade do carnaval brasileiro, por que então a "carioquização" e a "baianização" do carnaval são objetos de tão acirrados debates e ferrenhas lutas numa cidade como São Luís do Maranhão? Por que alguns atores sociais - intelectuais, artistas e cultores populares em particular (3) insistem tanto nas diferenças entre os carnavais, ressaltando o caráter especificamente maranhense de uma série de manifestações carnavalescas? Não quero questionar aqui a unidade postulada por Queiroz porque corresponde a um nível de verdade. Gostaria porém de enfatizar as diferenças que, na década de 1990, chegam a assumir um papel central na definição identitária dos maranhenses. Também em São Luís, a imitação de padrões importados foi vista durante muito tempo como natural e signo de "progresso" por intelectuais e artistas. Esta visão tem sido radicalmente questionada por um amplo movimento que pretendeu resgatar o carnaval "autenticamente" maranhense e que teve bastante êxito, a ponto de tornar-se hegemônico em 1999. Há vários anos que o carnaval em São Luís dividiu-se em três festas bastante distintas, até em sua configuração espacial: o Carnaval de Passarela no Anel Viário, no centro, onde domina o desfile das escolas de samba maranhenses (o modelo carioca), o carnaval de trio da Avenida Litorânea (o modelo baiano) e o Carnaval de Rua, em diversos bairros da cidade, onde se destaca o bairro boêmio da Madre Deus.

Este artigo pretende analisar as transformações recentes. O sucesso relativo de cada tipo de carnaval é o resultado de um complexo jogo de influências e interesses, em que intervêm, além dos foliões ávidos de brincar da melhor maneira, poderosos interesses que vão desde os governos estadual e municipal até a mídia nacional, passando pelas empresas locais até as transnacionais atuantes na cidade.

É necessário situar o carnaval na ilha do Maranhão dentro do campo da cultura popular e da cultura de massa. As discussões recentes em torno destes conceitos têm sublinhado a dificuldade de delimitar ambos. "A multiplicidade do sujeito popular complica a noção mesma de cultura popular" (4). O caso do carnaval são-luisense mostra, como veremos, esta crescente interpenetração. Tradicionalmente, existem três ciclos festivos maiores na parte setentrional do Maranhão: o junino, o natalino e o carnavalesco. O ciclo natalino perdeu em importância relativa, como no resto do país (me refiro a manifestações tradicionais como reisados e presépios, não à cultura de consumo). Contrariamente a outras regiões, o ciclo junino continua, de longe, o mais importante. No município de São Luís, registram-se três vezes mais organizações juninas que carnavalescas. As festas juninas são menos submetidas a influências externas, já que na maioria dos estados e sobretudo no Sudeste o carnaval é a festa maior. Cabe salientar também que existem múltiplas relações e influências entre o ciclo junino e o carnavalesco, porque são praticamente os mesmos indivíduos que mantêm ambas as práticas festivas. Como diz um cultor popular: "Nós temos dois corações: um boieiro e outro carnavalesco" (5).

O carnaval, construído e consagrado desde os tempos de Getúlio como a expressão típica de brasilidade (6), é de fato a marca registrada das velhas capitais: Rio 
de Janeiro e Salvador. Mesmo se, até a década de 1980, o Rio de Janeiro manteve um monopólio quase absoluto sobre a festa em termos de visibilidade na mídia e de padrão a ser imitado, Salvador nunca deixou de estar presente no carnaval e no samba carioca. Desde o período das "tias" baianas, no Estácio, ou na Mangueira, o Senhor do Bonfim tem sido cantado no carnaval carioca, e as alas das baianas fazem parte da definição mesmo de uma escola de samba. Esta presença, sem dúvida, ajudou a reemergência do carnaval baiano na consciência nacional na década de 1980. Neste quadro nunca houve muito espaço para qualquer carnaval fora do eixo RioBahia. O carnaval pernambucano parece ser o único que logra menção regular na mídia e, assim mesmo, sempre como álibi, como o carnaval que representa, para além do Rio e da Bahia, a existência de um outro Brasil no país do carnaval.

Existirá um carnaval maranhense que seja mais que um carnaval no Maranhão? É difícil de definir no que consiste exatamente o chamado carnaval maranhense, de traçarlhe limites que o demarcariam nitidamente dos outros carnavais brasileiros. Como veremos, em que consiste o especificamente maranhense constitui tema polêmico entre artistas, intelectuais e cultores populares. Desde a época colonial, manifestações externas foram introduzidas, reapropriadas e acabaram tornando-se maranhenses. A partir de quando adquiriram caráter "maranhense"? Poderia se argumentar que seria a partir do momento em que são produzidas no estado, com características próprias, e que o processo de diferenciação com suas fontes de inspiração chegou ao ponto de ruptura. Mas o caso do reggae jamaicano mostra que não existe consenso fácil. O reggae é tão popular no estado que a ilha de São Luís chega a ser chamada de "Jamaica brasileira" (7). Já existem grupos maranhenses que tocam um reggae local, e até um reggae-boi. Mas a música consumida nas reggaeterias de São Luís (ainda?) é jamaicana. Por esta razão, a maioria dos artistas e músicos locais protesta com veemência contra a qualificação, pela mídia, de

São Luís como "Jamaica brasileira”, considerada irresponsável e ignorante das tradições "genuinamente" maranhenses.

Existe, à semelhança da "baianidade", uma certa idéia do Maranhão como distinto do resto do país (8). Trata-se de um "arsenal simbólico", um conjunto de idéias e práticas que são reconhecidas como "maranhenses" e que sustentam os diferentes discursos regionalistas, perseguindo objetivos muito diversos, mas encontrando-se na defesa “do que é nosso". Poderíamos identificaros mitos constitutivos desta idéia do Maranhão. Em relação ao carnaval, por exemplo, há uma imagem poderosa no inconsciente coletivo, constantemente reiterada pela mídia, de que o carnaval de São Luís já teria sido - numa idade de ouro situada na primeira metade do século - “o terceiro do país”. Inútil dizer que os critérios para tal classificação nunca são justificados. Não quero, porém, limitar-me aqui a um exercício "deconstrutivista”, mas tentar entender uma dinâmica de transformação sociocultural mais ampla, onde este discurso intervém. Depois de caracterizar cada tipo de carnaval, mostrarei as lutas travadas para impor cada modelo. O meu enfoque para entender o processo de resgate será principalmente sobre o bairro da Madre Deus, que se tornou o símbolo da resistência maranhense contra a homogeneização imposta por fora.

\section{O CARNAVAL MARANHENSE ANTIGO}

\begin{abstract}
"Minha gente dá licença que eu agora tô chegando tô chegando sem trabalho para mostrar o meu baralho" (Joãozinho Ribeiro, do CD Pajelança, de Rosa Reis).
\end{abstract}

Devido à falta de pesquisas mais detalhadas, qualquer tentativa de periodizar o carnaval maranhense - mais adequado seria dizer ludovicense (9) - só pode ser extrema-
5 Entrevista com Basílo A. dos Santos, do grupo Fuzileiros da Fuzarca, "A Fuzarca dos Fuzileiros", in O Imparcial, 4/2/ 1999

6 Para uma contribuição recente sobre este tema, ver Hermano Vianna, O Mistério do Samba, Rio de Janeiro, J. Zahar, 1995

7 Ver a respeito do reggae no Maranhão: Carlos Benedito Rodrigues da Silva, Da Terra das Primaveras àllha do Amor. Reggae, Lazer e Identidade Cultural, São Luís, EDUFMA 1995

8 Para uma discussão da "baianidade", ver: Osmundo S. de Araujo Pinho, "'A Bahia no Fundamental': Notas para uma Interpretação do Discurso Ideológico da Baianidade", in Revista Brasileira de Ciências Sociais, 1, 36, 1998, pp. $109-20$

9 Existem festas carnavalescas, com características próprias em outros municípios do Maranhão, como Cururupu e Barra do Corda. 
mente provisória. Em muitos aspectos e nas linhas gerais, sua evolução, até a década de 1980, enquadra-se na periodização estabelecida para os outros carnavais no Brasil(10): a existência do Entrudo, desde os tempos coloniais, mas reprimido a partir da segunda metade do século XIX, a sua substituição pelo modelo veneziano, o aparecimento de cordões e ranchos populares, a partir do final do século XIX, e das escolas de samba, a partir da década de 1930.

No entanto, algumas peculiaridades merecem ser destacadas. A repressão (ainda não documentada para São Luís) ao Entrudo não resultou no seu desaparecimento, subsistindo brincadeiras de Entrudo (sobretudo com maisena) até os dias de hoje (11). Queiroz salientou que o modelo
Bicho Terra

no centro da

cidade,

carnaval de

1995 veneziano do Grande Carnaval, que prevaleceu no Rio de Janeiro, São Paulo ou em Salvador, não se impôs com a mesma força nas cidades brasileiras de segunda ordem (12). Como em Olinda, isto talvez tenha levado, em São Luís, à sobrevivência de manifestações anteriores como o congo, a chegança, ofandango e o coco (13). Além destas manifestações parecidas às que se festejavam nas demais regiões do Brasil (às vezes sob denominações diversas), era popular em São Luís a caninha verde. Brincadeira trazida do Minho, Portugal, consiste em canções e uma representação dramática. Originariamente tratava-se de um divertimento ligado ao fim das colheitas, uma brincadeira de roda envolvendo homens e mulheres (parecida com quadrilha junina). Urbanizou-se no Maranhão, tendo versões carnavalescas frequientes até 1950 e ainda é apresentado ocasionalmente (14).

Uma segunda fase do carnaval, que Ananias Martins chama de "Carnaval dos Cordões”, se iniciaria a partir do final do século XIX até aproximadamente 1970. Qualificada em geral como a "fase mais rica e complexa do carnaval de rua que São Luís já conheceu" (15), caracteriza-se pelo enfraquecimento das brincadeiras mencionadas, o desaparecimento dos autos e o surgimento de um conjunto de manifestações novas do tipo cordões, ranchos e corsos

Zilmar Fernandes \& Companhia Barrice

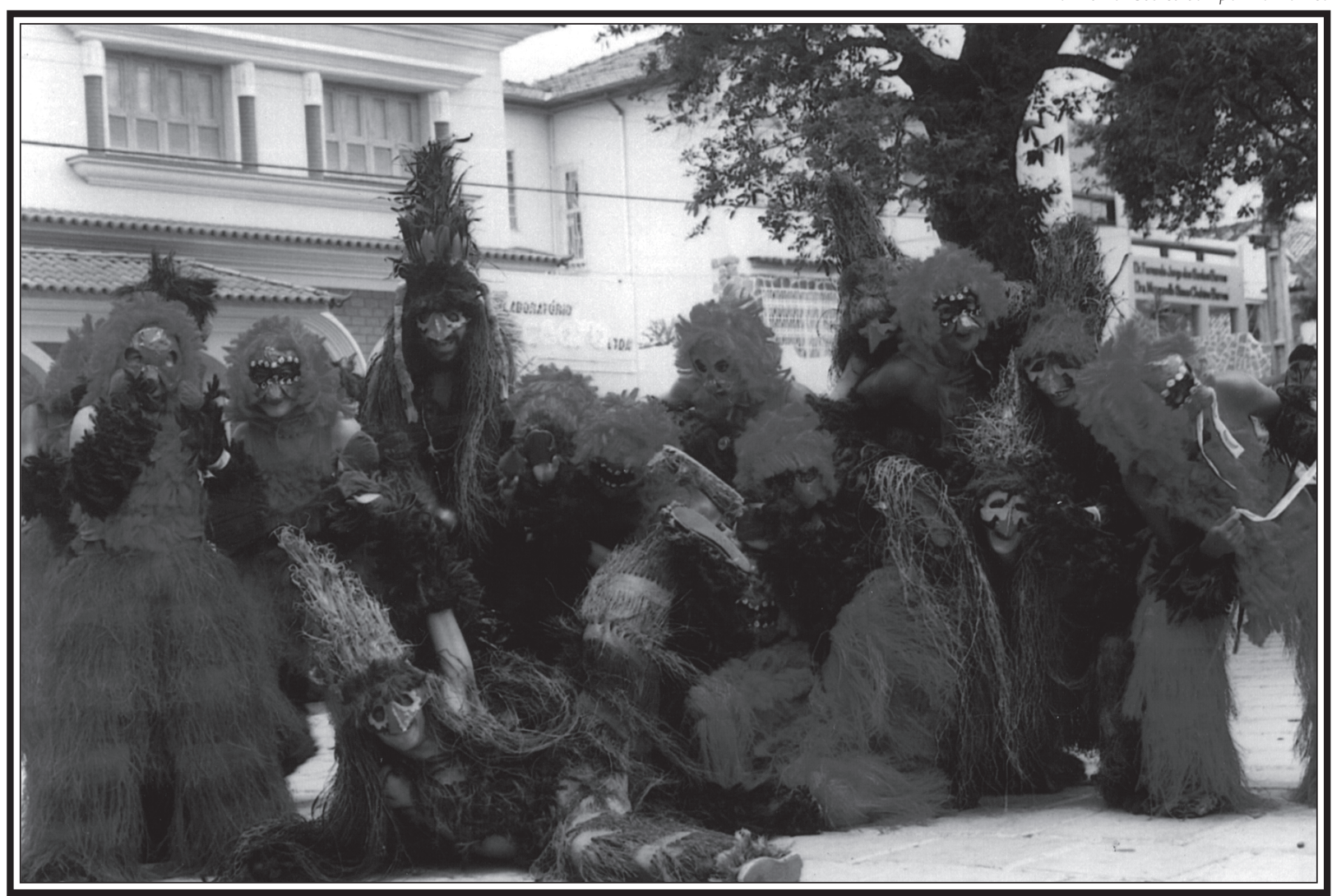


que se implantavam então também em outras cidades brasileiras.

Na ilha de São Luís, os cordões eram formados de personagens do carnaval europeu, como os dominós, os pierrôs, os cruzdiabos e os fofões, que convergiam no centro da cidade. Geralmente não dispunham de música ou dança própria, mas cantavam as músicas na moda. O fofão é um palhaço vestido de imenso macacão de chita colorida, com guizos e máscara de papel, grude e palha. Este personagem tenta convencer os transeuntes a pegar uma boneca que carrega, obrigando estes a pagarem uma prenda em seguida. O fofão é uma espécie de curinga que cabe em qualquer outra manifestação carnavalesca da cidade e, apesar de sua longínqua origem européia, acabou tornando-se o símbolo mesmo do carnaval maranhense. Isto é justificado à medida que o fofão caracteriza-se por uma linguagem corporal muito específica (saltos, paradas, gemidos), que expressam algo do jeito de ser maranhense.

Os ranchos distinguiam-se dos cordões por serem acompanhados de instrumentos mais sofisticados (charanga) e possuir ritmos específicos. Em São Luís eram famosos os cordões e ranchos de ursos, apresentando autos com "ursos caprichosos", cachorros e outros personagens. O urso também é um caráter carnavalesco de origem européia, que se adaptou ao meio equatorial, e para tal passou por um série de metamorfoses.

Outra manifestação central do carnaval maranhense era o baralho, descrito por Domingos Vieira Filho como consistindo "essencialmente de bandos de negros e negras esmolambados, pintalgados de tapioca de goma, empunhando sombrinhas e chapéus de sol desmantelados e sem pano, que percorriam as ruas da cidade numa gritaria infernal, ao som de reco-recos, pandeiros e violões" (16). Faltam pesquisas sobre esta brincadeira, bastante original por sua coreografia e sua música, assim como a sua contribuição para o samba maranhense. Finalmente, cabe mencionar aqui o tambor de crioula. Parente distante do samba de roda baiano, é uma brincadeira dedicada sobre- tudo a São Benedito. Acontece em qualquer época do ano, mas é apresentado com mais freqüência durante o carnaval e nas festas juninas (17).

Se a burguesia ludovicense não logrou imitar seus congêneres do Sul com os desfiles de grandes sociedades na rua, conseguiu emulá-la na organização de bailes mascarados nos clubes e nos corsos. Havia os bailes de máscaras da elite, nos clubes Cassino ou no Lítero, mas também os chamados bailes de segunda das classes populares, como nos clubes Bigorrilho, Berimbau, Cabeção, Cantareira e Furna de Satã. A grande atração para as mulheres era que podiam escapar, por breves horas, do domínio opressivo da moral patriarcal tradicional (18). Esses bailes conheceram seu auge na décadas de 1940 e 50; mas em 1965 o prefeito Cafeteira proibiu as máscaras, o que levou à rápida extinção dos bailes de máscaras, na sua forma antiga.

Corsos, ou passeatas de veículos transformados em alegoria, com passageiros fantasiados, às vezes com banda, organizaram-se desde o início da década de 1920 (19) e até o início da década de 1960 contavam com grande número de participantes e platéia. A profusão de carros deixou esta brincadeira típica de classe alta sem atrativo para a mesma, levando a sua desaparição (20). No entanto, um corso "popular" tem sobrevivido até hoje: a famosa Casinha da Roça, criada na década de 1940 para mostrar a cultura rural aos citadinos, ao som dos tambores de crioula (21).

Paralelamente, emergia outro tipo de bloco, chamado ulteriormente de tradicional ou de ritmo. Caracteriza-se por grandes tambores com uma batida própria, um samba de ritmo lento, introduzido já na década de 30 pelo bloco Vira-lata (22). Inicialmente formado por rapazes de classe média, foi constituindo gênero próprio nas décadas ulteriores, chegando a ser considerado um grupo específico nos concursos carnavalescos promovidos pelo Estado até hoje. Além disso apareceram na década de 1950 , em vários bairros do centro, mas de origem mais popular, as tribos de índios. Influenciados pelos filmes de bangue-bangue, deno-
10 Ver Olga R. de Moraes von Simson, "Espaço Urbano Folguedo Carnavalesco no Brasil: uma Visão ao Longo do empo" in Cadernos do Ceru, 15, 1981, pp. 297-305; Queiroz, Carnaval Brésilien op. cit., pp. 55-62, 163-9.

11 "O Ressurgimento do Entrudo no Carnaval", in O Imparcial, 25/2/1982. A referência mais antiga ao Entrudo no Maranhão, ao meu conhecimento, é a notícia no jornal 0 Globo de 1854, encontrada por David Touro Linger: Dangerous Encounters. Meanings of Violence in a Brazilian City Stanford, Stanford Univ. Press, 1992, p. 64

12 Queiroz, Carnaval Brésilien op. cit., p. 163

13 Ananias Alves Martins, Carna val de São Luís. Diversidade Tradição, São Luís, Func 1998 , p. 20. Registra-se em São Luís também a proibição de cheganças, congos, tandangos (Martins, p. 19)

14 ldem, ibidem, p. 28

15 ldem, ibidem, p. 34

16 Citado em Martins, Carnava de São Luís, op. cit., p. 40.

17 Sérgio Figueiredo Ferretti et. al. (eds.), Tambor de Crioula. R tual e Espectáculo, 2ำed., São Luís, Comissão Maranhense de Folclore, SECMA, lithograf 1995, pp. 56, 135, 137.

18 Para uma análise detalhada destes bailes, ver: Sandra Maria Nascimento, Mulher Folia. A Participação das Mu Iheres nos Bailes de Máscaras do Carnaval de São Luís nos Anos de 1950 a 1960, São Luís, SECMA, 1998.

19 Martins, Carnaval de São Luís, op. cit., p. 43

20 Queiroz, Carnaval Brésilien op. cit., p. 18

21 "A Cultura da Roca", in O Imparcial, 12/2/1999.

22 Ver a este respeito a reporto gem: "Carnaval ÉAlegria e Criatividade" in Vagalume, Su plemento Cultural SIOGE, março-abril de 1994 (São Luís 
23 Sobre a violência no carnava de São Luís, ver: Daniel Linger, Dangerous Encounters.

24 Para um relato das mudança introduzidas na Turma do Quinto, ver o depoimento de Luís de França em Memória de Velhos. Uma Contribuição à Memória Oral da Cultura Popula Maranhense, volume II, São Luís, Secretaria de Cultura, Centro de Cultura Popular Domin gos Vieira Filho, 1997, pp. 25 82. Ver também o número especial: "Carnaval Maranhense", in Boletim da Comissão Maranhense de Folclore 4 São Luís, 1996

25 Queiroz, Carnaval Brésilien op. cit., pp. 55-6, 167-9.

26 Rachel Soihet, A Subversão pelo Riso. Estudos sobre Carnaval Carioca da Belle Époque ao Tempo de Vargas, Rio de Janeiro, Fundação Gețlio Vargas, 1998 , pp. 52,58 120. minavam-se Apache ou Sioux, abrasileirando seus nomes ulteriormente para Tupis, Carajás e Upaon-Açu (nome tupinambá da ilha de São Luís). À diferença das tribos baianas, não tocam samba, mas têm um ritmo próprio. Eram reputados pelas confrontações violentas que resultavam do encontro de duas tribos nas ruas do centro, mostrando que a violência no carnaval não é somente um fenômeno recente (23).

Inspirados pela emergência do samba carioca, mas com características peculiares, onde perdurariam algumas tradições locais anteriores, surgem as turmas de samba na ilha do Maranhão. A primeira sendo a Mangueira, do bairro de João Paulo, fundada em 1929, logo seguida por outras, como a Turma do Quinto da Madre Deus (1940), a Águia do Samba, do Anil, A Flor do Samba, do Desterro, e a Favela do Sacavém. Inicialmente, não se diferenciava rigidamente blocos e turmas. Ambos desfilavam pelo seu bairro de origem e pelo centro da cidade, vestidos com as cores do grupo, mas não necessariamente com uma fantasia nova a cada ano. Cantavam sambas de autoria própria, dos compositores do grupo, mas não existia enredo. O primeiro concurso promovido pelo comércio local de que temos notícia foi organizado pelo Instituto de Beleza Vênus, em 1940. Ali participaram indistintamente turmas e blocos de samba e também o agora famoso Fuzileiros da Fuzarca, fundado em 1936 (24).

É necessário, no entanto, distinguir o momento de surgimento das turmas e blocos de samba, a partir do final da década de 1920, quando coexistem com muitas outras brincadeiras, e o momento de seu predomínio institucional, entre 1970 e 1985. Outra questão, que mereceria pesquisa mais detalhada, é a do nível da participação popular no carnaval são-luisense. O grande número de folguedos carnavalescos especificamente populares, na cidade, mesmo anterior a 1910, sugere que as classes subalternas nunca foram apenas espectadores de um "grande carnaval" festejado pela elite, como sugerido por Queiroz (25). Pelo contrário, como Raquel Soihet mostrou no caso do Rio, as classes populares sempre estiveram presentes, participando do carnaval de rua (26). O que mudou foi a visibilidade dos folguedos destes grupos, a sua percepção e representação pela mídia.

\section{AS TRANSFORMAÇOEES DO ESPAÇO URBANO}
“A Madre Deus chorou pelo seu pedaço de chão pelas pontes, pelas fontes, pelos rios pelos manguezais que não voltarão a Madre antes de tudo é o pescador que também chora, que também sente [a dor o pescador sorri com o mar na sua boca com o rio nos seus olhos com a rede em suas mãos mas o bicho homem o desencantou por isso a Madre Deus chorou, por isso a Madre Deus chorou" (Bulcão, do CD Bicho Terra).

As transformações do carnaval ludovicense, a partir da década de 1970, somente são inteligíveis tendo-se em conta a radical transformação do espaço urbano no mesmo período. A população do município de São Luís quase triplicou em 25 anos, passando de menos de $250 \mathrm{mil}$ (1970) a aproximadamente 825.000 (1995). O tombamento do centro histórico impediu um crescimento vertical e resultou na rápida expansão da cidade para áreas novas, além dos rios Anil e Bacanga que circundam o velho centro. A construção da ponte sobre o Rio Anil iniciou a urbanização do litoral ao Norte do centro histórico, onde se desenvolveram bairros de classe média e alta como São Francisco, Renascença, entrecortados por algumas áreas populares contíguas. A ponte sobre o Rio Bacanga, para o Sul, levou à criação de bairros populares como o Anjo da Guarda, Sá Viana e a Vila Embratel. Na década de 1980, prosseguiu a urbanização da orla, constituindo-se ali um anel de bairros "nobres", indo da Ponta d'Areia ao Araçagi, passando pelo Calhau e pelo Olho 
d'Água. A construção da Avenida Litorânea, na década de 1990, seguiu o modelo de outras cidades do litoral brasileiro.

Neste quadro, o bairro da Madre Deus ocupa uma posição bastante singular. $\mathrm{O}$ bairro surgiu originalmente ao redor de uma ermida dedicada a Nossa Senhora da Madre de Deus, situado numa ponta de terra alta, conhecida como Ponta de Santo Amaro, posteriormente transformada em hospital militar. No início, a sua população era constituída sobretudo de pescadores, que atracavam seus barcos à beira do Rio Bacanga. A existência de uma zona alta, próxima ao centro histórico, levou à instalação do cemitério, e de várias fábricas têxteis no início do século XX, assim como do matadouro municipal em 1936. A Madre Deus transformou-se então em um bairro não somente de pescadores, mas, também, de operários, e atraía migrantes do interior (27). A construção da barragem do Bacanga no fim da década de 1960 deslocou os barcos das circunvizinhanças, e uma parte da população para os novos bairros. Apesar destas mudanças, o bairro se consolidou: como não havia mais espaço para expansão, os migrantes do interior passaram a dirigir-se preferencialmente a outros bairros, mais periféricos. A contigüidade com o centro histórico - algumas ruas com casas de estilo colonial, tombadas pelo município, de fato terminam no bairro - resultou num certo "emburguesamento" da parte alta da Madre Deus. Ou seja, a área hoje chamada de Madre Deus é constituída por uma área "mista", onde se encontram um bairro com habitações de classe média e/ou de classe média baixa (São Pantaleão, Madre Deus “de cima") e praças, largos e avenidas largas, com um bairro de classe média baixa e pobre (Madre Deus “de baixo") Além do mais, a Madre Deus é contígua a outros bairros populares, como o Goiabal, o Lira, o Belira e a Coréia, que passaram por processos similares de consolidação. Residir ali é atrativo para pequenos funcionários e empregados no comércio, devido à proximidade ao centro. Aqui a Madre Deus recruta grande parte dos seus brincantes, os quais consideram os largos e praças dela como seu reduto natural de lazer.

Esta é, em resumo, a situação relativamente privilegiada da Madre Deus, em comparação com outros bairros populares do centro, ou bairros periféricos. O crescimento da cidade levou à transformação e ao esvaziamento de bairros outrora populares, como o Desterro e o Santo Antônio, que não dispõem mais de uma substancial população para manter suas tradições festivas. Quando falamos da Madre Deus como um bairro “popular", é imprescindível ter em mente que se trata de um popular específico, característico de um bairro velho, estabelecido, com moradores de segmentos sociais diferenciados. Possui características muito distintas do "popular" das invasões mais recentes (tipo Coroadinho) ou das urbanizações distantes (tipo Maiobão). Não quero aqui forçar a especificidade da Madre Deus. Existem outros bairros com forte tradição de "folclore", como a Camboa, a Liberdade, o João Paulo, o Anil e até os conjuntos habitacionais mais velhos (Cohab) ou as misturas de conjuntos e invasões mais antigas (como o Anjo da Guarda). No entanto, nenhum deles possui o conjunto de características próprias a Madre Deus, aliando tradição à heterogeneidade social e localização favorável. Poderíamos dizer que a Madre Deus consegue o equilíbrio frágil de ser abastada o suficiente para sustentar numerosas brincadeiras, e de permanecer popular o suficiente para que estas permaneçam "autênticas".

O surgimento da Madre Deus como o "bairro de resistência" da cultura popular tem portanto uma longa história. Os registros atestam que a maioria de pedidos de brincadeiras juninas e carnavalescas já provinha desta área da cidade no século XIX (28). As duas casas de culto afro-maranhense mais antigas - atualmente existentes - também estão situadas no bairro, na área de São Pantaleão. Como ali também fixaram residência artistas e músicos, há uma tradição adicional de boemia que coexiste com seu caráter operário, pescador e funcionário. Em outras palavras, trata-se de um bairro com uma composição social e cultural extrema-
27 Abmalena Santos Sanches, Capricho do Povo. Estudo so bre o Bumba-meu-boi da Ma dre Deus, monografia de ba charelado em Ciências Sociais, UFMA São luís, mimeo 1997, pp. 24-8; Luiz Antônio Pinheiro, O Canto do Maguari. Estudo da Escola de Samba Turma do Quinto, monografia de bacharelado do Curso de Turismo UFMA mimeo. 1991, p. 19: Jomar Moraes, Guia de São Luís do Maranhão, São Luís, Legenda 1989, pp. 181-2.

28 Emanuela Sousa Ribeiro, "Re querimentos de Licenças para Festas na Secretaria de Polícia de São Luís (1873-1933)". Relatório de pesquisa do pro eto "Religião e Cultura Popu r" coordenado por Sérgio Figueiredo Ferretti, São Luís mimeo., 1998 
mente heterogênea, difícil de encontrar em outros bairros da cidade.

Apesar ou talvez por causa desta heterogeneidade, o bairro logrou forjar uma identidade forte, da qual não somente os sucessivos Bois, mas também a escola de samba Turma do Quinto, foram, durante muito tempo, a expressão maior. Esta identidade do bairro alimenta ao mesmo tempo que vive do mito de uma comunidade ideal. O mito de uma "república madredivina" pode ocultar que o bairro também é prisioneiro do sistema de clientelismo e dominação vigente, e que, justamente por causa da sua heterogeneidade, é submetido a conflitos internos significativos. A força do mito pode constar-se pelo grande número de indivíduos que se identificam com o bairro, mesmo residindo fora dele. Eles consideram que têm um vínculo com a Madre Deus, seja porque já moraram ou se criaram ali, seja porque fazem parte de um grupo cuja sede é no bairro. Pertencer à comunidade ideal da Madre Deus é como professar fé no valor do folclore regional, é constatar que, além de todos os debates sobre a cultura popular, ela acontece, e com tremenda força, nessa região do Brasil, e nesse bairro.

O reconhecimento oficial da Madre Deus como bairro detentor de potencial folclórico é antigo, sem que isto tenha resultado, durante muito tempo, em melhorias significativas na sua infra-estrutura. $\mathrm{Na}$ década de 1980 o abastecimento de água e os sistemas de esgotos ainda eram muito precários. Uma mudança importante ocorreu em 1998, quando o governo estadual iniciou o Projeto Viva. Partindo do pressuposto de que o bairro "encena um espetacular intercâmbio de vidas, onde a arte, a crença e o lazer se fundem na formação de um promissor pólo de turismo cultural para o Estado" (29), o governo investiu na melhoria da infra-estrutura urbana, urbanizando os principais largos, praças e avenidas, a maioria dos quais é parte do circuito de carnaval ou local dos festejos de bumba-meu-boi, e reformou o espaço Ceprama, situado numa antiga fábrica têxtil, com a construção de uma arena com arquibancadas, palco e outras instalações.
Somente no ano seguinte, começou obras similares em outros bairros populares, que entretanto não receberam investimentos da mesma importância.

\section{O CARNAVAL CARIOCA OU DE PASSARELA DO SAMBA}

\author{
“Tupã! Oh Tupã! \\ Floresce entre as tuas aldeias \\ Tupã! Oh Tupã! \\ O grito da tribo guerreira \\ que a ilha, ainda, continua \\ nos braços de outra bandeira [...]" \\ ("Upaon-Açu", enredo da Turma do \\ Quinto de 1982, de Bulcão, Sapo, César \\ e Zé Pereira).
}

A partir dos anos 1970 o carnaval maranhense entrou em nova fase, com a adoção plena do padrão carioca. Apesar de o samba de passarela ter se tornado então hegemônico, é importante notar que nem todas as brincadeiras da fase anterior desapareceram. Muitas conseguiram coexistir com o novo tipo de carnaval, mesmo não dispondo mais da sua antiga força.

O papel da mídia foi fundamental na imposição do novo modelo. As revistas do Sudeste (Manchete, Fatos e Fotos, etc.) divulgavam as fotos das fantasias cariocas, cada vez mais luxuosas. Jornalistas como Jota Alves e Fernando Souza, da Rádio Difusora local, comentavamos detalhes dos desfiles das escolas do Rio. A Rede Globo, que vinha fortalecendo o seu predomínio em nível nacional durante os anos de chumbo da ditadura, começou a transmitir as impressões e as imagens do carnaval carioca ao vivo. Desde então, o carnaval carioca tornou-se onipresente nos lares maranhenses durante o período momesco. Assim, "só na década de 1970, as turmas de São Luís, que vinham percorrendo um caminho criativo relativamente autônomo, irão incorporar 'novidades' que as aproximem da exuberância do carnaval carioca, influenciadas pelas imagens televisivas já 
em expansão na capital" (30).

A influência do modelo carioca levou as turmas e alguns blocos a transformaremse em escolas, apresentando um sambaenredo para um desfile com alas e carros alegóricos. Na Turma do Quinto, esta ruptura aconteceria a partir de 1974, consumando-se definitivamente em 1978 com o enredo de I-Juca Pirama (31). Surgiu então, à semelhança do Rio de Janeiro, a figura do carnavalesco, cujo papel intromissor nesta cidade foi criticado por autores como Rodrigues (32). Numa cidade média como São Luís nessa época, no entanto, esta inserção não assumiu formas de imposição cultural tão extrema, devido ao fato que a distância social que separava o carnavalesco da comunidade não era tão abismal como no Rio de Janeiro, com sua oposição morro contra asfalto. O carnavalesco da Turma do Quinto, Tácito de Borralho, por exemplo, bacharel em filosofia, com mestrado em São Paulo, diretor de vários grupos de teatro, viveu sua infância e adolescência no bairro (São Pantaleão), resultando desta convivência laços de amizade que antecederam a sua função (33).

Todas estas influências novas não deixavam de resultar em mudanças estéticas significativas. Até 1980, usava-se muito material regional, mas, como as comissões julgadoras pareciam preferir fantasias luxuosas, as escolas “botaram brilho". Quando uma escola do Rio inovava nesta área, podia também encontrar ecos em São Luís: assim a Flor do Samba repetiu o bloco dos mendigos da Beija Flor.

A concorrência entre as grandes escolas Flor do Samba, Mangueira, Turma do Quinto e Favela mobilizava os foliões. A competição entre as escolas tornou-se destarte um aspecto central do carnaval maranhense. A briga pelo título refletia-se até na desunião entre as escolas. Havia a União das Escolas de Samba do Maranhão, dominada pelas grandes escolas como a Turma do Quinto, e a dissidente Federação das Escolas de Samba do Maranhão, tendo à sua frente a Flor do Samba, tradicional rival da Turma do Quinto. Mesmo se alguns políticos influentes se associaram com determinadas escolas, dando-lhes apoio de diversos tipos, as escolas, nesta fase, não deixavam de representar a sua comunidade, e os seus anseios. Existia também um certo consenso sobre a coabitação entre a escola e os blocos. Assim a Turma do Quinto representava a união do bairro - $a$ Madre Deus. Os blocos desfilavam nos outros dias, mas, no domingo gordo, todos vestiam-se com as cores da escola, de azul e branco para desfilar na avenida. Algumas escolas, fortes deste seu respaldo pela comunidade, tentavam levar mensagens mais políticas para a avenida. Por isso, alguns dirigentes da Turma do Quinto diziam: "Nós sempre levamos sambas de oposição” (34).

Por outro lado, as empresas locais, se não descobriram, pelo menos intensificaram seus investimentos no carnaval para promover seus produtos. O Estado, delegando a organização da festa durante vários anos à empresa maranhense de turismo (Maratur), deixava também claro a que fins deveria servir. O carnaval de passarela constituiu um campo onde diversos grupos tentaram influenciar a opinião pública, como pode ser ilustrado pelo carnaval de 1982. Desde o ano anterior, o planejado projeto Carajás havia levantado muita polêmica na cidade. Formou-se um movimento amplo contra a instalação da Alumar, consórcio das empresas transnacionais Alcoa e Billington. O governador João Castelo estava facilitando a montagem de uma grande unidade de produção de alumínio na ilha, sem muitas exigências em relação à poluição que iria causar. Os apelos por parte da população e dos grupos ambientalistas - temia-se a contaminação das águas do golfo, e de suas adjacências, que forneciam subsistência e trabalho para milhares de pescadores - não foram atendidos.

Duas escolas aludiram no seu enredo ao que era sentido por muitos como uma grave ameaça ao equilíbrio ecológico da ilha. Os Unidos da Camboa escolheram a denúncia aberta e direta, o que não deixou de ter conseqüências imediatas: um dos seus carros alegóricos, que fazia menção explícita à poluição da Alcoa, foi apreendido
31 Depoimento de Jeová França. Ver também: Pinheiro, $O$ Canto do Maguari, pp. 31-2, 47

32 Ana Maria Rodrigues, Samba Negro, Espoliação Branca São Paulo, Hucitec, 1984, pp 42-53.

33 Ver também Pinheiro, 0 Canto do Maguari, p. 38

34 ldem, ibidem, p. 43

35 "Governo Desestimula Carno val de São Luís", in Folha do Maranhão, 25/2/1982 
pela Polícia Federal (35). O samba ("O risco do progresso é o povo sem marisco, e o povo sem marisco, o progresso corre risco") recebeu nota baixa da comissão julgadora, acusada, então, pelo autor do samba Chico da Ladeira de ser infeudada à mesma Alumar (36). "O samba mais divulgado em todas as emissora de rádios e TV e na própria passarela da Deodoro foi o produzido pela Alcoa/Alumar, em resposta ao samba da Camboa, composto por Oberdan, do Grupo Nonato e seu conjunto" (37).

A Turma do Quinto escolheu um protesto mais sutil. O seu enredo Upaon-Açu não mencionava o nome da empresa, mas traçava as sucessivas invasões da ilha, terminando com "a tristeza derradeira do suicídio metálico" (38). O refrão, que levantou a platéia, apelava a ir "à luta contra o invasor". Talvez porque a mensagem tenha sido sutil demais, ou porque houve um problema com o último carro alegórico na hora do desfile, este protesto passou desapercebido para muitos não-iniciados, e a escola chegou a ser bicampeã nesse ano.

Em que pese o entusiasmo dos foliões, é importante esclarecer que as dimensões do Carnaval de Passarela nunca chegaram nem perto do seu modelo de inspiração em termos de orçamento. Tanto o governo do Estado quanto a prefeitura nunca puderam ou quiseram contribuir com somas significativas, e as reclamações das escolas a este respeito têm sido constantes nos últimos trinta anos. Além do mais, o estado geralmente não tem conseguido garantir um mínimo de eficiência no fornecimento da infra-estrutura. A mudança do desfile da Praça Deodoro para o Anel Viário não foi acompanhada de um investimento de infraestrutura, as arquibancadas são sempre montadas na última hora e deixam muito a desejar. Os apelos para construir um sambódromo ainda não foram ouvidos. As escolas não podem contar com generosas doações de bicheiros nem com direitos de transmissão televisivas, que contribuem substancialmente para financiar o luxo das escolas cariocas. O patrocínio do comércio local é modesto em termos quantitativos. Poucas empresas podem permitir-se o de- senvolvimento de programas na área de cultura como a Alumar. Assim, a tensão entre a expectativa de um carnaval ao modo carioca e a realidade dos desfiles maranhenses nunca foi superada (39).

Apesar da imposição inicial, o Carnaval de Passarela passou por um processo intenso de adaptação ao meio maranhense, ao ponto de constituir, no final do século XX, uma manifestação que já consta de uma tradição própria, original. A crise e os conflitos originam-se na intersecção de vários problemas: financeiros, partidários, identitários, e, sobretudo, a competição com os outros carnavais.

\section{O CARNAVAL BAIANO OU DA LITORÂNEA}

Se influências do carnaval baiano podem ser detectadas a partir do final da década de 1980, é com a criação do Carnaval da Litorânea, em 1994, que a "baianização" do carnaval assume proporções tais que se constitui em carnaval próprio, competindo com os outros. Aproveitando-se do novo espaço da Avenida Litorânea, o "Carnapraia", como também é chamado, foi antes de tudo uma criação de empresários querendo repetir em São Luís os bons negócios do carnaval de trio baiano. Consiste aqui também em trios elétricos puxandoblocos, cujos integrantes são protegidos por cordões de isolamento do resto dos foliões, que não puderam ou não quiseram pagar pelo "kit" dando direito ao abadá, alguma bebida e atendimento médico. $\mathrm{O}$ pioneiro foi o trio Ilha, seguido pelo trio Maravilha. No carnaval de 1994 saíram os blocos Grafitti, Xique e Ilha. Segundo o seu organizador, Walfredo Dantas, o bloco Xique saiu então com 1.500 integrantes e 200 seguranças. Os abadás eram vendidos a 50 ou 60 reais, pouco em comparação com a Bahia, mas muito em comparação com os salários médios de São Luís. O trio Maravilha, com uma potência de 100.000 watts, foi montado em Salvador. Os gastos 
com a montagem e as bandas fazendo a animação custaram em torno de US\$ 1 milhão (40). Em outras palavras, foi preciso um investimento importante de grandes empresas privadas para viabilizar este tipo de carnaval. O bloco Xique é patrocinado pelo restaurante que leva seu nome, no retorno do São Francisco. Os trios Maravilha e Ilha receberam patrocínio do Sistema Mirante de Comunicação (grupo ligado à família Sarney, que controla a estação de rádio e o canal de televisão do mesmo nome, além do jornal $O$ Estado do Maranhão), Bacanga Sonorizações e a Brahma. Outro trio, chamado Pingüim, foi patrocinado pela Antarctica e a prefeitura (41).

A mídia logo passou a apoiar o carnaval baiano. Já no sábado de carnaval $O$ Imparcial publicava uma matéria - debaixo do rótulo "Alumar Cultura" - com a manchete "Na Onda do Carnaval Elétrico. Trios Fazem a Festa na Avenida Litorânea e Lançam a 'Baianificação' do Carnaval Maranhense", em que declarava:

“A invasão das ruas de São Luís pelo carnaval nos moldes baianos já é uma realidade e vem causando polêmica entre a classe artística que joga tudo para a preservação das tradicionais brincadeiras de rua. Mas os trios elétricos estão aí e a verdade é que a 'baianificação' da Av. Litorânea vem arrastando, neste período carnavalesco, milhares de pessoas que, faça sol ou faça chuva, preferem cair na folia perto do mar.

Mais do que os foliões, estão animados com este rentável empreendimento, os empresários que apostaram todos os 'centavos' na música que vem de Salvador” (42).

Não deixa de ser lógico que os grupos que estavam engajados diretamente no lançamento do carnaval baiano se empenhassem também em divulgá-lo. O Estado do Maranhão repetia a dose no dia seguinte. Com a manchete "São Luís Quer Ser Bahia”, publicou uma matéria que já anunciava, de maneira peremptória, a vitória do novo tipo de carnaval:
“Quem se orgulha de ver São Luís pela ótica dos velhos carnavais, puxados por blocos de rua vai ter que se render à potência dos decibéis dos trios elétricos. São eles que comandam o carnaval em todo o país. A Bahia inventou e inovou e, como em todos os quatro cantos, nossa cidade só quer ser Bahia.

Este ano a iniciativa privada investiu pesado na Avenida Litorânea como palco e nos trios como maestros. Clubes, blocos e fofões de rua ficam para depois da festa na praia. Toda a programação veio sob o molde da folia baiana, inclusive o figurino. Não venham dizer que perdemos as características, que este não é o nosso carnaval ou entrar no mérito de uma discursão [sic] sobre indústria cultural.

A invasão da música baiana em todas as praias, se para alguns é lamentável, para tantos outros, pelo menos nesse período, é período, é pura festa” (43).

Enquanto estes jornais pelo menos cobriam com outras matérias o carnaval das escolas e blocos, a TV Mirante parece que nesse ano só tinha olhos para a festa abaianada: não se via outra coisa na cobertura do carnaval. A única e breve reportagem sobre São Luís divulgada pela Globo, em nível nacional, também mostrava os trios na Litorânea, como se este fosse o único carnaval da ilha. Tendo visitado os três espaços nesse ano, posso dizer que o número de pessoas na Litorânea, de maneira nenhuma, ultrapassou a multidão que freqüentava o carnaval de rua nos diversos bairros da cidade.

Mas a matracagem da mídia não deixou de ter seu efeito. Dois anos depois, os quatro blocos desfilando na Litorânea já venderam 11.000 abadás, protegidos por 600 PMs e 300 seguranças privados (44). A grande novidade do ano 1997 foi o bloco Reggae Itanatty, patrocinado pela cervejaria Schincariol. Puxado pela banda maranhense Guetos, contando com a participação especial do cantor jamaicano Eric Donaldson, cerca de 3.000 pessoas desfilaram neste bloco, nas cores do reggae e do nacionalismo pan-africano, amarelo, verde e vermelho.
40 "Na Onda do Carnaval Elétrico", in Caderno Impar, O Im parcial, 25/2/1995.

41 "São Luís Quer Ser a Bahia", in Caderno A-alternativo, OEs tado do Maranhão, 26/2/ 1995

42 Caderno Impar, O Imparcia $25 / 2 / 1995$

43 Caderno A-alternativo, $O E s$ tado do Maranhão, 26/2 1995

44 "Trios Arrastam Multidão", in O Imparcial, 10/2/1997. 


\section{"A MÁQUINA DESCASCAR'ALHA 0 BICHO". 0 "RESGATE" DO CARNAVAL MARANHENSE}

\author{
"Você saiu \\ pensando que o bloco fosse terminar \\ é engano seu \\ estou aqui para representar \\ eu vou descendo \\ eu vou descendo devagar \\ com meu batuque ritmado \\ para a avenida apresentar \\ sou Fuzileiro \\ sou Fuzileiro de coração \\ 64 anos de glória \\ no carnaval do Maranhão"
}

(Juarez Assunção, dos Fuzileiros da Fuzarca).

$\mathrm{Na}$ verdade, o carnaval de rua nunca desapareceu por completo em São Luís. Brincadeiras de rua continuaram a existir nos diversos bairros da cidade mesmo durante a proeminência absoluta do carnaval de estilo carioca. Escolas como a Turma do Quinto sempre honraram a memória do carnaval antigo (45). Mas o enfraquecimento de muitos grupos era evidente. Por exemplo, os tradicionais Fuzileiros da Fuzarca deixaram de sair durante vários anos na década de 1970. Entre mais de 40 tribos de índios que chegaram a existir num só carnaval, somente três ou quatro sobreviviam no início da década de 80 (46).

A idéia de "resgate" do folclore sempre aparece em contextos históricos específicos. No Brasil, o processo de democratização coincidiu com a redescoberta do Brasil e do seu folclore (47). Na verdade, desde 1973, com o grupo Cazumbá, houve um grupo de teatro e dança já preocupado em apresentar bailes juninos desconhecidos no resto do país. O grupo Pai Simão, a partir de 1980 , fez do resgate de uma dança do interior o seu programa. Em outras palavras, o resgate do folclore já estava em gestão; estes e outros grupos iniciais foram importantes para a formação de uma nova geração de artistas e cultores populares decididos a lutar pela preservação do que consideravam o patrimônio cultural da cidade e da região. Inicialmente concentrado nas festas juninas, o movimento começou a se preocupar também com o carnaval. É a partir de 1984-85 que ocorre o gradual ressurgimento do carnaval de rua. Originou-se na insatisfação com o carnaval de passarela, cuja desorganização foi sempre alvo de crítica, assim como a "marmelada" na hora de decidir os vencedores dos concursos. Em 1983 e 1984, não sendo conquistados títulos importantes pelos grupos da Madre Deus, reforçou-se a sensação de exclusão no bairro (48). O bloco Caroçudo organizava “domingueiras" para revitalizar o largo da Avenida Rui Barbosa (posteriormente rebatizado "Largo do Caroçudo"). Ao mesmo tempo, surgiam, em outros contextos e outros bairros, novos blocos alternativos. O mais importante é, sem dúvida, o bloco Akomabu. Militantes do Centro de Cultura Negra, fundado em 1979, percebiam que o CCN "desaparecia” no carnaval, porque seus membros saíam em alas da Turma do Quinto, da Favela ou em outros grupos. A partir desta reflexão, surgiu a idéia de colocar um bloco na rua que fosse mais identificado com o emergente movimento negro na região (49). O Akomabu, cujo nome significa, em fon, "a cultura não deve morrer", saiu pela primeira vez em 1984. Chegou a ter até 3.000 integrantes, levando Magno Cruz, um dos idealizadores e ex-presidente do CCN, a qualificá-lo de "maior instrumento educacional de massa do Movimento Negro maranhense" (50). A inspiração inicial veio da Bahia, tanto que o primeiro ritmo tocado era afoxé (51), e enredos e fantasias seguiam um padrão de bloco afro. Mas o Akomabu passou logo a tocar também ritmos de tambor de mina. O Abibimã, outro bloco afro que surgiu na década de 90, inspira-se no ritmo do tambor de crioula.

A partir de 1987, o grupo Fuzarca fazia shows na praça pública, valorizando um repertório de músicas do carnaval maranhense (sambas de compositores maranhenses, tribos, marchinhas antigas). 
Na mesmaépoca, constata-se um crescimento dos blocos tradicionais (ou "de ritmo") que, apesar de desfilar na passarela, sempre saíram nas ruas dos respectivos bairros. A partir de 1988, assiste-se ao "resgate" de brincadeiras antigas, como o Urso Caprichoso. O grupo de teatro Laborarte começa a organizar o "carnaval de segunda", em 1990, convidando todos os grupos do carnaval de rua a congregar-se em novo espaço, na rua e praça frente ao casarão colonial que ocupa, no centro. Até hoje constitui um evento maior do carnaval de rua em São Luís (52).

Mais tarde, o mesmo Laborarte apresentaria o espetáculo de carnaval "Te gruda no meu fofão", que mostra um fofão encontrando brincadeiras do carnaval de rua antigo. Em 1989 surge o Bicho Terra, uma brincadeira nova, mais inspirada em ritmos do carnaval de rua antigo (tribo de índios e outros) e usando materiais regionais (palha de buriti) na confecção de suas fantasias.

Os blocos não exerciam muita influência nas associações existentes (União e Federação das Escolas). No auge da crise da passarela criou-se a Associação de Blocos Carnavalescos do Maranhão, em 1990, que agrega os blocos alternativos e tradicionais (incluindo os Fuzileiros da Fuzarca). A direção, constituída por representantes dos Brasinhas, dos Unidos do Codozinho e dos Versáteis, sugere um circuito alternativo na área de São Pantaleão, em 1990. Seminários promovidos pelo Centro de Cultura Popular, em 1990, ajudaram a promover a discussão entre os diferentes grupos. O primeiro e modesto apoio oficial começou em 1991. Depois de muitos trâmites, a Comissão de Carnaval do Município aceitou fornecer informalmente uma estrutura de som ao bairro da Madre Deus para o carnaval de 1991. Já nesse ano houve também um tímido apoio da parte do governo Edison Lobão. Nerine Lobão, à frente da Secretaria da Cultura, deu outra ajuda de custo para as instalações na Madre Deus. Desta maneira, os responsáveis pelo projeto carnaval de rua da Madre Deus buscavam, nas palavras de um dos idealizadores, o compositor e líder do grupo Bicho Terra, Zé Pereira Godão, "costurar os dois apoios", conseguindo al- guns elementos básicos, como refletores, estrutura de som e transporte para as apresentações dos grupos. Inicialmente, a improvisação era muito grande: em 1992, por exemplo, usaram-se as sobras da decoração da passarela do ano anterior.

Em 1994, o diretor de teatro, ex-carnavalesco da Turma do Quinto e presidente da recém-criadaFundação de Cultura, Desporto e Turismo do Município (Func), Aldo Leite, inverteu as prioridades: o município iria apoiar antes de tudo o CD. A Func criou um programa específico de apoio ao carnaval de rua em 1993, proclamando: "O carnaval é de rua". No carnaval de 1995 , a prefeitura financiou a infra-estrutura básica (sonorização, iluminação, decoração, posto médico volante, segurança, trânsito) em oito bairros. Havia circuitos de rua, não somente nos bairros mais tradicionais e centrais, como São Pantaleão/Madre Deus, Liberdade e Fátima, mas também em bairros periféricos, como Cidade Operária e Santa Cruz. Aproximadamente 40 grupos receberam uma pequena gratificação para apresentar-se nos circuitos no sábado e domingo de carnaval. Além do mais, a Func apoiou festas de rua pontuais em outros dez bairros (53). Uma "Barca da Folia" com dominós, pierrôs, colombinas, cruz-diabo e fofões tentava reviver a tradição dos corsos.

Em 1999, o governo estadual apoiou o carnaval de rua em todos os bairros onde desenvolvia projetos Viva. A prefeitura financiou circuitos em nove outras comunidades e também a Passarela do Samba no Centro. Desta maneira, o carnaval de rua conseguia apoio substancial ou mesmo prioritário das duas instâncias de poder - uma vitória ao fim de longa e persistente luta por mais espaço contra muitas adversidades.

\section{A LUTA PELA HEGEMONIA CULTURAL NO ESPAÇO PÚBLICO}

\author{
"A gente precisa é lutar pela \\ Camisa da Madre Deus"
}

52 "Laborarte Mantém Tradição da Segunda. Festa Carnava lesca Animada por Artistas Maranhenses Reuniu na Jansen Muller Crianças e Intelectuais" in Caderno Cidade, O Estado do Maranhão, 16/2/1999.

53 Ver o folheto "Carnaval 95. de Rua. É da Gente", São Luís, Func, 1995. 
(do samba em homenagem ao compositor Tabaco, de César Teixeira).

Apesar de o carnaval de rua ter sido um sucesso pelo menos desde 1995, em termos de animação nos diferentes circuitos, e do número de pessoas de todas as idades assistindo, a mídia local o ignorou na prática durante vários anos. A televisão concentrava-se sobre o carnaval da Litorânea ou da Passarela. As reportagens no Estado e no Imparcial em 1995 só mencionavam os grupos do carnaval de rua quando passavam na passarela. Uma matéria neste último restringiu-se a comentários críticos ("A Prefeitura colocou a barca na rua e se esforçou muito para decorar os bairros da cidade, mas parece que faltou enfeite") ou mesmo irônicos, ressaltando que um trailer na Madre Deus tocava música baiana (54). Os carnavais da Passarela e da Litorânea ainda recebiam toda a atenção das reportagens (55).

Mesmo nos anos seguintes (1996 e 1997), O Estado ainda declarava que “a av. Litorânea está definitivamente consagrada como o point da folia maranhense" (56). Mas já destacava a animação do circuito da Madre Deus e o sucesso da Máquina de Descascar Alho (bloco de sujo da Madre Deus). Entre 1994 e 1999 o carnaval de rua logrou ocupar cada vez mais espaço, tanto na realidade concreta (número de foliões brincando nos bairros)

A competição entre os três carnavais foi explícita desde o início. O carnaval representa um dos momentos em que a população está na rua - já que Passarela e Litorânea desenvolvem-se também na rua, mesmo que não sejam o carnaval de rua (57). É portanto compreensível que tanto o Estado (governos municipal e estadual) quanto os grandes grupos econômicos não queiram deixar passar a ocasião para lançar a sua mensagem, ou direcionar o evento numa direção que lhes pareça favorável. Vimos a intervenção no carnaval de passarela da maior empresa transnacional presente na ilha, já na década de 80 , buscando através desta via conseguir maior aceita-

ção entre a população. O mais novo ator no carnaval maranhenseé a igreja católica que, reconhecendo o potencial do carnaval em termos de relações públicas, promove desde 1993 um retiro espiritual de massa durante os dias de folia momesca (o chamado Rebanhão). Criou também em 1999, à imagem do carismático padre Marcelo Rossi, um Bloco do Terceiro Milênio, em que o povo de Deus desfila pelos bairros, fantasiado de fofão, atrás do cardeal.

A boa ou má organização do carnaval, inevitavelmente, terá resultados nas contendas eleitorais futuras. A mídia da situação sempre busca realçar a boa organização e o eficiente policiamento do carnaval, permitindo à população brincar tranqüilamente, enquanto a mídia da oposição tende a enfatizar a desorganização e a violência do mesmo, que seria o reflexo da ineficiência do governo. Entrecruzam-se desta maneira interesses comerciais imediatos com interesses de relações públicas a médio prazo, além dos projetos próprios aos grupos carnavalescos, que, na busca de apoio financeiro, entram em acordos com políticos e empresários.

Não posso aqui fazer a história extensa deste complexo jogo de influências e interesses, porque os acordos, em geral, fazemse em recintos fechados. Gostaria de mostrar apenas o papel de manipulação da mídia nesta luta; e como a política do Estado e a de grupos ligados a este passaram por reorientações importantes, contribuindo para a consagração recente do carnaval de rua; e finalmente como, apesar de tudo, estratégias alternativas têm conseguido conquistar espaços. O carnaval constituiu-se num campo em que estas forças se opõem e se combinam, gerando uma dinâmica própria que nenhum dos atores controla totalmente.

A manipulação mediática é fácil de constatar, comparando-se a cobertura do carnaval pelos diferentes órgãos da imprensa. Os mesmos fatos são relatados de maneira contraditória. Por exemplo, no carnaval de 1997, O Imparcial destacava-se por uma crítica violenta ao carnaval de passarela, cuja “desorganização" seria o "principal tema de um enredo que não consegue se desenvolver na avenida” (58). Dos 2.000 quanto na virtual (mídia). Mais", in O/mparcial, 11/2/
1997. semiprivado. Têm perdido multo público nos últimos anos.
54 "Bobagens Carnavalescas", in como Point da Festa", in $\mathrm{O}$ 1996. "Carnapraia Consagra Folia da Litorânea", in O Estodo do Maranhão, 10/2 1997 
espectadores nas arquibancadas, pouco mais de 100 teriam resistido até o final (59).

Já $O$ Estado do Maranhão reinterpretou a falta de organização e infra-estrutura na passarela num sentido mais positivo: "A irreverência e a espontaneidade substituíram o luxo no desfile das escolas de samba e blocos organizados de São Luís. A forte chuva que caiu durante a madrugada não tirou o brilho do desfile e nem afastou o público, estimado em mais de três mil pessoas (sic)" (60). Somente o Jornal Pequeno defendeu a passarela a todo custo, intitulando sua reportagem: "Nem chuva, nem carnaval baiano conseguiram estragar a festa com as arquibancadas lotadas até o clarear do dia (sic). Blocos e Escolas deram show no Anel Viário" (61). Como se vê, a percepção de uma mesma realidade não deixa de ser bastante diferente segundo os interesses dos donos da mídia.

Mesmo quando o fato relatado é similar, a interpretação dele é que faz a toda a diferença. Em 1999, os blocos da Litorânea Xique e Tchêquerê se juntaram num só bloco. O Imparcial, que desde 1997 adotou uma posição crítica em relação ao carnaval da Litorânea, explicou: "Os primeiros indícios de que a folia baiana no Maranhão iria fracassar apareceram logo que os dois blocos se juntaram. Segundo relataram diretores dos blocos à coluna, isso aconteceu porque a venda de abadás foi fraca, ou seja, abaixo da expectativa. No final, tinha folião vendendo abadá pela metade do valor que havia adquirido, mas, mesmo assim, estava difícil passar a camiseta" (62). Já $O$ Estado do Maranhão, um dos principais promotores do carnaval da Litorânea, conseguiu reinterpretar fracasso em sucesso: “A animação dos foliões na Litorânea [...] demonstrou que o bloco Xiquerê, nascido da fusão dos blocos Xique e Tchêquerê, foi mesmo aprovado". Citando opiniões de foliões e de um integrante do grupo Marafolia, co-responsável pela promoção do carnaval da Litorânea, sugeria que "a idéia da fusão dos blocos [...] partiu dos próprios associados" (63).

Parece também que o papel da mídia restringe-se muitas vezes a afirmar o que já é consagrado, ao invés de estar atento ao que é novo. O Estado do Maranhão dedicava assim tremendo espaço ao show de Alcione (64). Mas não mencionava que, no dia anterior, a cantora tinha se apresentado diante de uma passarela quase vazia, enquanto o grupo de pagode Regional 310 tocava a pouca distância de lá, no auditório do Ceprama completamente lotado. Ou seja, a notícia importante, do meu ponto de vista, nesse momento, era que a nova geração de músicos da Madre Deus alcançava a preferência do público sobre uma consagrada estrela do samba. Importante seria então perguntar-se se isto não se deve ao fato de Alcione, apesar de suas origens maranhenses, ser ainda identificada com o samba carioca que sempre cantou, e não com a reemergência do samba maranhense que os foliões queriam valorizar naquele momento.

A manipulação mediática não é nova nem específica ao Maranhão e poderiam se multiplicar os exemplos, destacando-se a cobertura da televisão. O que porém é interessante são as mudanças de posições em relação aos diferentes carnavais. No início da década, toda a mídia ignorou completamente o carnaval de rua. Enquanto O Estado do Maranhão embarcou numa defesa incondicional do Carnapraia, O Imparcial, que inicialmente também parecia acatar a baianização como inevitável, começou, a partir de 1996-97, a apoiar o carnaval de rua e juntou a crítica da Litorânea à sua já tradicional crítica da passarela. O Estado, diante do crescimento do carnaval de rua, não podia mais ignorá-lo totalmente e passou, a partir de 1997, a dedicar-lhe matérias extensas, sem contudo questionar a preeminência do carnaval da Litorânea - no qual tem, afinal, interesses diretos. Em 1997 escrevia ainda que "o Carnapraia consagrou definitivamente a avenida Litorânea como o principal (sic) ponto da folia de São Luís"; mas já destacava que, "no circuito de São Pantaleão, uma multidão foi animada pelo tradicional carnaval de rua maranhense" (65). Como a partir de 1998 o governo estadual tivesse passado a investir prioritariamente no carnaval de rua através dos projetos Viva, o jornal também deixou
59 "O Carnaval da Resistência", in O Imparcial, 11/2/1997

60 "Desfile da Irreverência", in 0 Estado do Maranhão, 11/2/ 1997

61 Jornal Pequeno, $11 / 2 / 1997$

62 "Roça Total", in O Imparcial $18 / 2 / 1999$

63 "Trios Elétricos Sacodem a litorânea", in O Estado do Maranhão, 16/2/1999

64 "Show de Alcione Fecha Temporada de Carnaval" in $\mathrm{O}$ Estado do Maranhão, 18/2/ 1999

65 "Carnapraia Consagra Folia da Litorânea": "Bicho Terra Máquina de Descascar'alho Revivem Tradicional Carnava no Circuito de Rua", in O Estado do Maranhão, 10/2 1999 
de defender incondicionalmente o Carnapraia, optando, em vez disso, por uma posição neutra com a senha: “A ordem é liberar geral" (66). As extensas matérias cobriam então os três carnavais, sem distinção, mas as fotos de primeira página eram de preferência da Madre Deus (67). O Imparcial foi mais longe e, conforme a minha própria observação, ficou mais perto da "verdade", intitulando sua reportagem principal da quarta-feira de cinzas: "Madre Deus consagrada a dona do Carnaval 99”. Declarou um dia depois, que "foi um fracasso total o Carnaval privado que aconteceu na Litorânea [...] A maioria dos foliões, em vez de ir para a Litorânea, foi mesmo para a Madre Deus". De fato, como pude constatar, não somente os foliões, mas os vendedores ambulantes também transferiram-se em massa da Litorânea para a Madre Deus.

Quanto às razões, O Imparcial explicava que "o fracasso do carnaval privado tem algumas explicações: o desgaste da axémusic, os altos preços dos abadás e o principal - o sucesso do genuíno carnaval maranhense na Madre Deus" (68). O sucesso do "genuíno" certamente deve muito à insistência dos artistas e cultores populares na frente dos grupos do carnaval de rua, resistindo às imposições de outros carnavais, e perseguindo tenazmente um carnaval alternativo. Lograram convencer não somente as massas dos foliões, mas também políticos e dirigentes de empresas, que passaram a apostar no carnaval de rua. Aproveitaram-se até da tradicional concorrência entre o governo municipal e do estado, conseguindo recursos de ambos para o carnaval de rua. O governo estadual por exemplo gastou, em 1999, R \$250.000 com o carnaval, não incluindo as despesas com os projetos Viva. Se isto é bastante comparado com anos anteriores, ainda é pouco se comparado com as despesas para São João, que alcançaram em 1998 - ano de eleição - mais de um milhão de reais. De qualquer maneira, o carnaval movimenta somas cada vez maiores.

A intervenção dos poderes públicos, da mídia, das empresas e o próprio sucesso do carnaval de rua não deixam, por sua vez, de influenciar a maneira como este acontece, e toda a estrutura que o sustenta. Tentarei, na última parte deste trabalho, refletir sobre alguns resultados deste carnaval resgatado para o bairro, e para a cultura na cidade e no estado.

\section{REALIDADE E MITO DO RESGATE}

A distinção entre os três carnavais não deixa de ser esquemática e simplificadora, a realidade sendo, como sempre, muito mais complexa. Para começar, a separação não foi e nem é total entre os três espaços. Alguns grupos do carnaval maranhense, como o Bicho Terra em 1995, apresentaram-se na Litorânea com o intuito de alcançar também este público. Isto sempre foi sistemático no carnaval da passarela: praticamente todos os grupos do carnaval "maranhense" desfilam em algum momento na passarela (escolas, blocos tradicionais, blocos, tribos, etc.). Além do mais, o carnaval da passarela não fica totalmente separado do carnaval de rua. De fato, a passarela tem sido montada nos últimos anos no Anel Viário, a pouca distância da Madre Deus, permitindo a ida e volta entre os dois, e assim aumentou ainda mais o atrativo deste último bairro como point mais quente do carnaval. Desta maneira, o carnaval de passarela depende do carnaval de rua, tendo este usado o espaço daquele para se promover. Esta interdependência poderia levar à conclusão de que deve haver espaço para os dois.

O carnaval "baiano" da Litorânea não deixou de apresentar algumas particularidades maranhenses, como o bloco dos "reggaeros" do Itanatty. Mesmo se oreggae é uma presença também no carnaval baiano, o estilo do reggae maranhense é distinto do baiano, tanto na dança (se baila junto no Maranhão) como na preferência por subestilos específicos (no Maranhão as músicas mais roots são as mais populares). Não se pode excluir a possibilidade, também para este carnaval, de desenvolver características próprias, ultrapassando o nível de simples réplica do baiano.

Da mesma maneira, as próprias mani- 
festações não são totalmente arredias às influências recíprocas. De fato, a baianização silenciosa das manifestações maranhenses segue a anterior carioquização. Alguns exemplos podem ilustrar este processo: os blocos tradicionais cantam, além das músicas de sua autoria, muitas das axémusics na moda. Sua roupa, no entanto, passou a seguir, nos últimos anos, o padrão carioca, destacando-se por fantasias cada vez mais brilhantes e de aparência "luxuosa", tendência aliás perceptível também em muitos grupos juninos, sobretudo o Boi de Orquestra. Grupos como Bicho Terra lançaram novas músicas, cujo estilo e coreografia aproximam-se do Tchan baiano. As coreografias, em geral, das escolas de samba para os grupos menores perderam muito do jeito maranhense de dançar, assemelhando-se mais às coreografias baianas. No desfile do Quinto de 1999, observei que apenas alguns foliões mais velhos sambavam como antes, as gerações mais novas estão decididamente abaianadas no seu estilo de mexer. Os recentes blocos de jegue também introduziram elementos "baianos", o Jeguefolia, por exemplo, desfilou no carnaval de rua com um minitrio. Além do mais, o carnaval baiano é um fenômeno heterogêneo. Acho que ninguém critica o Akomabu por ser "abaianado" - porque ele não se inspira dos trios mas em outra fonte, nos afoxés e blocos afros de Salvador que também inscreveram o resgate nas suas bandeiras.

As transformações recentes não deixaram de ter repercussões sobre os atores e os espaços envolvidos, generalizando ou reforçando mudanças já encaminhadas. A profissionalização dos cultores populares éfundamental neste contexto. Com o crescimento docarnaval de rua, o pagamento de cachês, por mais modestos que sejam, contribuiu para uma tendência crescente de profissionalização. Multiplicaram-se também as apresentações privadas remuneradas, assim como as gravações de LPs e CDs. Obviamente esta profissionalização não atingiu ainda as proporções cariocas ou baianas. Praticamente ninguém, ou muito poucos músicos, consegue viver de sua arte em São Luís. A maioria necessita de outro emprego, que pode até ocupar mais tempo que a música. O Estado tradicionalmente tem sido um refúgio para este grupo intermediário entre cultores populares e artistas que poderíamos chamar de semiprofissionais. Muitas repartições públicas, como a Secretaria de Cultura, constituíram-se em verdadeiro "viveiro" de cultores populares e artistas, assegurando entre um e três ou quatro salários mínimos a bom número deles. Se os salários são baixos, mesmo para padrões maranhenses, trabalhar para o Estado tem uma série de vantagens: não somente o expediente é reduzido a cinco horas de trabalho (das 13h às 19h), como também é mais fácil conseguir licenças para apresentações do que no setor privado, além da garantia de emprego para funcionários públicos.

Com o crescimento do carnaval de rua desenvolveram-se também os empregos remunerados na área de cultura popular, mesmo que seja somente durante as festas. Desta maneira, é comum ver-se os outrora boêmios do bairro ocupados agora na organização mesma do carnaval de rua ou de outra atividade a ela ligada, como as relações públicas. O carnaval, mesmo o de rua, está virando um negócio. Isto é aparente também na clara comercialização do bairro da Madre Deus, sobretudo na parte do circuito do carnaval. Todos os comércios da área têm lucrado com as festas no bairro, a ponto de muitas casas outrora particulares transformaram-se em comércios permanentes na Praça da Saudade e no Largo do Caroçudo. Além disso, muitos moradores da área transformam a sua casa em comércio temporário, que só funciona durante as festas (mas as festas são muitas!). Contudo, a institucionalização da Madre Deus como o bairro boêmio tem afastado moradores antigos, que não agüentaram mais algumas consequiências das repetidas festas - barulho, lixo e confusão. As transformações do carnaval e das festas juninas produzem assim uma reconfiguração do bairro, resultando no enriquecimento dos comerciantes locais, ou mais geralmente no melhoramento das condições socioeconômicas de muitos moradores implicados na organização da festa. Por outro lado, 
está resultando também na expulsão dos que não querem conformar-se com o caráter de boemia permanente, ou dos que não conseguiram participar das oportunidades econômicas que a festa oferece. Para constatar o processo de acelerada diferenciação social, basta olhar como algumas casas do bairro passaram por reformas custosas enquanto outras carecem ainda de conforto mínimo. Estas mudanças podem, num futuro próximo, afetar a coesão social do bairro ou mesmo resultar numa transformação completa de sua base social. O grande desafio para a antiga associação de moradores e o novo Conselho Comunitário da Madre Deus será o de enfrentar estes problemas.

A profissionalização está mudando também a relação entre os cultores populares e entre os grupos carnavalescos, além de afetar as práticas festivas. Enquanto no carnaval de rua antigo brincar era a finalidade principal, no carnaval de rua resgatado, ganhar o pequeno extra que permite equilibrar o orçamento familiar não deixa de ser uma preocupação central para os cultores populares como para os músicos profissionais. Antigamente os grupos recrutavam-se sobretudo por área geográfica, mas sem distinção maior entre músicos, destaques e foliões, resultando numa coesão relativa do bloco. Agora já acontece o contrário. Um grupo como o Bicho Terra, por exemplo, ocupava um espaço com a tremenda força do seu cordão e impressionava pelas muitas brincadeiras com as quais entretinha o público adulto e infantil. Nessa época era constituído por veteranos da fuzarca madredivina e as novas gerações do bairro, um bloco crescido em muitos carnavais. Agora limita-se a ter seu núcleo de músicos profissionais e a recrutar foliões avulsos pelos quatro cantos da cidade, que querem vestir a prestigiosa fantasia de palha do buriti colorida, mas sem ter a mesma noção da brincadeira. Os antigos bailarinos do bairro saíram todos à busca de oportunidades financeiras melhores, que o Bicho não podia lhes oferecer.

A comercialização não deixa de ter impacto sobre a própria maneira de brincar o carnaval. Nas noites de carnaval, de sexta a terça-feira, os fuzarqueiros da antiga estão ou tocando num grupo ou organizando o carnaval de rua ou vendendo comidas e bebidas. Quem se diverte livremente são os foliões do resto da cidade que vêm para a Madre Deus brincar. Parece que a hora de o bairro brincar, sem ter que atender a dezenas de milhares de foliões que vêm de fora, chega somente nas manhãs do carnaval, quando sai a Máquina de Descascar Alho, levando com ela grande bloco de sujo pelas ruas até o centro ou pelas ruas dos bairros adjacentes.

A incipiente profissionalização dos cultores populares contribui também para agravar a crise pela qual passam as escolas de samba. Muitos cultores populares nem desfilam mais porque têm outros compromissos. Se antigamente os blocos da Madre Deus dissolviam-se no domingo de carnaval, para seus integrantes desfilarem pela escola, representação máxima do bairro, os desfiles da Turma do Quinto, nos últimos anos, têm-se caracterizado mais pela justaposição de blocos: o Bicho Terra e o Tijupá desfilam enquanto tais dentro da escola. Sem dúvida, a popularidade destes blocos ajuda a animar a platéia em favor da escola. Por outro lado, reforça a crescente desagregação daquilo que era o símbolo por excelência do bairro.

O resgate do carnaval maranhense constitui desta maneira um processo complexo, em que o mito de resgatar o carnaval antigo nem sempre corresponde à vivência dos participantes. Em termos de manifestações, poderíamos distinguir as brincadeiras que continuam desaparecidas, como o fandango, ou sobrevivendo apenas em outros ciclos festivos, como o coco. Ainda há brincadeiras em processo de extinção, como a caninha verde. Entre as manifestações resgatadas, consta o urso caprichoso, o corso, o cruz-diabo; mas não atingiram a força de antigamente. O resgate do bara1ho, manifestação central do carnaval antigo, continua sendo parcial: muitos grupos tocam músicas de baralho, sem entretanto reconstituir a brincadeira como tal. O fenômeno de resgate parece-me mais notório nas brincadeiras que não se extinguiram 
por completo, e que foram reafirmadas: o tambor de crioula, os blocos tradicionais, as tribos de índios e os fofões. Finalmente, surgiram blocos recriados, que se inspiram do carnaval de rua antigo, mas são, na verdade, manifestações novas, como o Bicho Terra e a Máquina de Descascar Alho, e, mais recentemente, os blocos de jegue (Jegue Folia, Vagabundos do Jegue).

A reafirmação das antigas brincadeiras não aconteceu sem transformação: elas profissionalizam-se e perdem seu caráter, se não "espontâneo", pelo menos não comercial. Há uma tendência saudosista que vê isso como uma evolução apenas negativa. Entretanto, cabe ressaltar que o folclore que não busca adaptar-se corre o risco de acabar no museu. Mesmo no Maranhão, o carnaval é cada vez mais um evento da cultura de massa; quem não consegue o seu espaço na mídia corre o risco de desaparecer. Neste contexto é impressionante como alguns grupos, como Bicho Terra, Fuzarca, Serrinha e Cia. e o Regional 310 lograram ampla aceitação do público maranhense. Quando o Bicho saía, no início da década, tinha que levar a sua mensagem para os bairros com a força do seu cordão. Agora as músicas já estão tão populares que é a platéia, vestida com a camiseta que o grupo vende, que "entra no Bicho", onde este aparece, e transforma suas apresentações em delírio coletivo. Até uma manifestação tradicional como o tambor de crioula conseguiu crescer e adaptar-se ao carnaval de rua resgatado. Nos últimos anos, os grupos de tambor têm se multiplicado, a ponto de se registrarem somente em São Luís pelo menos 37 grupos (69). A Casinha da Roça já inspirou dois novos grupos de crioula que também saem num corso enfeitado como uma casa de palha: o Tijupá e a Tapera. $\mathrm{O}$ tradicional refrão "beirou, beira mar, beirou" virou um hit do carnaval maranhense, cantado por muitos outros grupos. Isso pode indicar que brincadeiras tradicionais como o tambor de crioula estão conseguindo dar o pulo para a modernidade. A globalização tampouco está ausente do carnaval de rua, mas poderíamos argumentar que ela se manifesta de maneira distinta. Os enredos do bloco Akomabu por exemplo, vinculando a luta do negro maranhense às lutas na diáspora, defendem um modelo de globalização alternativo.

Quanto às escolas de samba, uma das razões por que estão em crise é justamente a divergência que divide artistas, cultores populares e foliões sobre o que constitui o caráter "maranhense" e a tradição. Enquanto carnavalescos como Tácito Borralho defendem o desfile da escola de samba na passarela - afinal uma tradição velha de pelo menos três décadas na cidade -, outros, como o compositor e agora secretário de Cultura Bulcão, querem privilegiar uma tradição anterior: a das turmas de samba. Segundo eles, as escolas deveriam sair como as turmas de antigamente, com a batucada, e apenas um número limitado de "balizas" (passistas) fantasiados, incluindo porta-bandeira, mestre-sala, rainha e princesas. Atrás deles viria, como antigamente, o fuá (arrastão). É um pouco este modelo que a Turma do Quinto tem seguido na maioria dos carnavais da década de 1990, quando decidiu não concorrer, mas apenas desfilar de arrastão pela avenida, cantando não somente o samba do ano, mas também sambas de anos anteriores.

Como devemos interpretar, então, o resgate do carnaval maranhense? Não resta dúvida que este resgate é também uma modernização, mesmo se é feito sob o signo do tradicionalismo. Destarte, tanto o carnaval da Litorânea como o carnaval de rua constituem processos de modernização, caracterizados pela crescente profissionalização, comercialização e globalização. Mas trata-se de modelos competitivos de modernização. O carnaval da Litorânea seria o modelo "dependente", que segue mais estritamente um modelo importado, estimulando pouco a criatividade e a identidade local. É mais consumista e menos participativo, excluindo crianças e idosos. Trata-se de um processo de modernização homogeneizador, que reforça a tendência alienante dos maranhenses de identificarem-se apenas com outros lugares, a Bahia ou a Jamaica. É um processo de deses-
69 "Relação de Grupos de Tambor de Crioula", in Boletim Maranhense de Folclore, 3, 1995 , p. 7. 
70 "Carnaval - Aval da Carne", in O Estado do Maranhão 6/2/1999.

71 Para uma discussão do resgate do carnaval de Olinda, ver: Queiroz, Carnaval Brésilien op. cit., pp. 191-200.

72 "Globalization and the Crisis of the Popular", in Salman (ed. The Legacy of the Desinherited op. cit., pp. 263-76

73 Azevedo Neto, Bumba-meu-bo no Maranhão, p. 106

74 "Alcione Fala sobre o Carnaval", in O Imparcial, 13/2/ 1999

75 Para a distinção entre valoriza ção e preconceito em relação à cultura popular, ver: W. Beik, "The Dilemma of Popula History", in Past and Present 141 , 1993, pp. 209-11. truturação da personalidade própria ao colonialismo cultural, deplorada por escritores como José Chagas: “São Luís passa por ser hoje um lugar que não existe” (70).

O carnaval de rua constitui um modelo de modernização alternativa e apresenta características muito distintas de outros carnavais resgatados, como por exemplo o de Olinda (71). A riqueza e diversidade das manifestações, a sua criatividade exuberante, a sua descentralização e gratuidade, e a participação de todas as faixas etárias significam, potencialmente, a integração da periferia e uma democratização da festa. Conferem sentido de identidade regional importante para a reafirmação do sujeito e a recuperação da sua auto-estima, e a luta contra o centralismo homogeneizador, em nível nacional.

A transformaçãodocarnaval maranhense reflete também outro aspecto da modernização, salientado por Jean Franco: a abolição das fronteiras entre cultura popular e cultura erudita (72). Isto se vê pelo espaço que o carnaval agora ocupa na mídia, onde - apesar de manipulações já comentadas - são notáveis as mudanças tanto quantitativas quanto qualitativas: o incremento geral do número de matérias é acompanhado também de melhoramentos das reportagens, e uma diversificação do tipo de matérias, indo das crônicas históricas, editoriais, reportagens sobre grupos específicos às páginas dos colunistas sociais. Nesse sentido convém relativizar o que foi dito anteriormente sobre a manipulação da mídia, na medida em que todos os órgãos têm oferecido aos seus leitores, ouvintes ou espectadores uma informação mais variada, uma cobertura menos homogênea, aceitando opiniões divergentes nas suas colunas. Mais notável todavia são as mudanças ao nível do Estado, refletindo o realinhamento por parte das elites regionais. A Secretaria de Cultura foi, durante muito tempo, dominada por escritores querendo enfatizar a tradição da “Atenas brasileira”. Agora éliteralmente ocupada por compositores e músicos representantes da fuzarca madredivina.

Quanto à espontaneidade dos antigos carnavais, que o modelo alternativo preten- de resgatar,é difícil conciliá-lo sempre com as exigências da modernização. Como salientou Azevedo Neto, o fato de um conjunto ser tradicional não significa necessariamente que seja espontâneo, e vice-versa (73). A profissionalização, a comercialização e a crescente institucionalização do carnaval de rua tendem a limitar severamente a espontaneidade, se não dos foliões, pelo menos dos empregados da folia.

A consagração da Madre Deus não deixa de ter consequiências para os outros bairros. Podem se beneficiar, por um lado, do espaço agora concedido ao carnaval de rua. Por outro lado, como a Madre Deus tende a atrair toda a atenção, fica mais difícil para outros bairros se afirmarem. Se a Madre Deus representa a resistência cultural em nível regional, já representa o establishment em nível local. Como salientou o carnavalesco Chico Coimbra, a Madre Deus hoje é um espaço privilegiado, e falta levar esta revitalização aos outros bairros, para poder dizer que "teremos um Carnaval da Ilha" (74). Somente assim a lição de democracia, fazendo do bairro um exemplo de conivência, e não de exclusão, adquirirá todo o seu valor.

Reconheço que para o praticante de história imediata, é difícil não tomar partido. Creio, no entanto, que a opção de valorizar a cultura regional não significa necessariamente um enfoque preconceituoso (75). Assim, apesar de todas as contradições, limitações e problemas que o resgate do carnaval de rua de São Luís tem, acho que oferece um modelo que merece consideração e ampla divulgação.

“O Carnaval é a própria vida É a arte por toda parte portando o nosso estandarte recrutando fuzileiros pra defender nossas tribos! É o nosso grito guerreiro fazendo fulejo e fuzarca com água-benta da folia exorcizando todo o mal: - Nada para os infiéis! - Tudo para o CARNAVAL!" (Joãozinho Ribeiro, do CD Te Gruda no Meu Fofão, do grupo Laborarte). 